\title{
The galactic language
}

TOM MCARTHUR

\author{
Some comments on the power and prestige \\ of Californian usage at the end of the twentieth \\ century
}

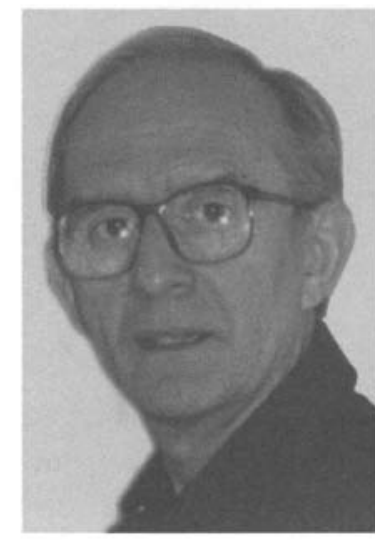

[The following article is a slightly adapted version of a talk given at an A-Level English Language Dayschool organized by the National Centre for English Cultural Tradition, the University of Sheffield, on 4 November 1998.]

LET'S SUPPOSE for a moment that we aren't in this splendid octagonal building in Sheffield at the close of the twentieth century but in Ops [the Operations Room] on a space station called Deep Space Nine, four hundred years in the future and somewhere out beyond Altair and Betelgeuse. An alien appears on the viewscreen in front of us - someone with power shoulders and pointy ears, and he is seated on the bridge of a Romulan warbird. Captain Benjamin Sisko of Star Fleet greets the visitor firmly but with respect, and after a moment's silence the Romulan replies - in a Liverpool accent. Or a Glasgow, Dublin, Australian, Indian, Singapore, or Sheffield accent.

It wouldn't be right, would it?

But this is not because we expect Romulans to speak their own language. We've never heard them do that since Star Trek began. We expect English from them, as we expect it from just about every alien we've ever encountered in all the variations of the Star Trek saga. Whether we think about it or not, however, we don't expect just any English from the Romulans, Klingons, Cardassians, and all the rest. We know that aliens in fact speak American English. And not just any American English.
Even in the farthest depths of the Delta Quadrant, where the starship Voyager is limping 70,000 light years home, such beings use Californian English.

\section{The right accent}

For certain purposes in English-language radio, television, and cinema some accents are right and others wrong. Thus, in the original Star Trek series in the 1950 s it was fine if Montgomery Scott, the chief engineer of the Enterprise, had a Scottish accent - even if it was produced by a Canadian with an Irish name, James Doohan. This was because the Scots have for decades been internationally associated with ships' engines. There's even a poem by Rudyard Kipling to prove it, called McAndrew's Hymn, which is addressed jointly

TOM McARTHUR was born in Glasgow in 1938.
A graduate of Glasgow and Edinburgh universities,
he has been an officer-instructor in the British
Army, Head of English at the Cathedral School,
Bombay, organizer of courses for overseas students
at the University of Edinburgh, associate professor
of English at the Université du Québec, and is
currently an Honorary Fellow of the University of
Exeter. His publications include the 'Longman
Lexicon of Contemporary English', 'A Foundation
Course for Language Teachers', Languages of
Scotland', 'Worlds of Reference', 'The Oxford
Companion to the English Language', 'The English
Languages', and Living Words'.


to heaven and the mighty engines that he serves:

I canna get my sleep tonight; old bones are hard to please;

I'll stand the middle watch up here - alone wi God an these

My engines, after ninety days o race an rack an strain

Through all the seas of all Thy world, slambangin home again.

The international and now intergalactic cliché of Scots and their engines is fine, and runs on into the early episodes of The Next Generation first with a woman, Chief Engineer MacDougall, then with a Lieutenant Commander Argyle, both of whom were however duly replaced by a truly politically correct figure: Geordi La Forge, a visually challenged black American male fitted with compensatory optical technology. It was also all right in the Original Series if the ship's surgeon Leonard McCoy sounded like a country doctor from Missouri, because that's where he was supposed to come from - but it would have been all wrong if $\mathrm{Mr}$ Spock from the planet Vulcan had had a Southern or an Irish or even an East Coast American Jewish accent (which would have fitted the Boston background of Leonard Nimoy, the actor who played the part). Spock had to be vocally undistracting, because the rest of him the ears, the eyebrows, the green blood - were distracting enough. And only a general smoothed-out American accent would fit that bill, for both Americans and the world at large.

So, for some purposes and under certain circumstances, some kinds of English are more equal than others. The key reason of course is that the episodes are made in America for Americans - and not in New York or Chicago but Los Angeles, where the actors needed for all kinds of roles (and, if necessary, accents) can be found. Which is all rather like the BBC when it started up in London in the 1920s. Then and for several generations afterwards, the British grew entirely used to hearing the news and other high and serious matters presented in Received Pronunciation, the prestige but minority accent of the monarchy, the aristocracy, the upper middle class, and the 'public' schools, whereas sports and gardening and one or two other areas of radio and television could safely be left to people with broader and earthier accents.

\section{Californian English}

But there is more to California than Star Trek and Hollywood. There are two other areas where this particular state of the Union sets the pace and a large part of the standard for English and indeed the world. One centres on the New Age movement and a style of speech that has been called 'psychobabble' - mixing the usage of the hippies, of therapy, of the women's movement, and of social consciousness-raising generally, and laced with a fuzzy eager informality often associated with the socalled Valley Girls in and around Los Angeles. The other belongs to Silicon Valley, whose usage is part of 'computerspeak' or 'computerese', which belongs within a wider but mainly US phenomenon called 'technobabble' - a term also used to describe the technical jargon of Star Trek.

In 1980 the British novelist and academic David Lodge published a widely-praised article called 'Where it's at: California language'. I looked at it again before coming here, in order to find some suitable words and phrases. But I couldn't. Like I mean I couldn't do that anymore, because everybody kinda does it now. Like it's everywhere, and I'm like wow! So we all just gotta hang in there and everybody and everything has chilled out.

The other California-speak can be found in such works as The Hacker's Dictionary, edited by Eric S. Raymond (MIT Press, 1991). Thus, crufty means 'poorly built' and footprint is the desk area taken up by a piece of hardware, and a brain dump is telling someone everything you know, an activity analogous to a core dump (which is a complete copy of the contents of a core or main storage unit, dating from the ferrite-core memory, back in the electronic Iron Age). Nothing ages as fast as hacker slang. And it has some real curiosities: as for example wank, a term that in all probability began this stage of its existence at Columbia University, being, before that, no more and no less than the British word we all know so well. But I quote from the dictionary:

A noun denoting a clever technique or person or the result of such cleverness. The adjective wanky describes something particularly clever (a person, program, or algorithm).

Conversations can also get wanky when there are too many wanks involved. This excess wankiness is signalled by an overload of the wankometer. When this happens, the 
conversation's subject must be changed, or all non-wanks will leave.

The dictionary then notes that the usage is American only: 'In Britain and the Commonwealth,' it adds, 'this word is extremely rude and is best avoided.' And for modesty's sake, no further details are supplied.

The use of this word is like the issue of accents. Wank poses no problem for American hackers. The compiler could have the entry in his dictionary because the word is so utterly harmless and inoffensive in the US - and so little known there in its non-American role. I can only use it here, of course, because I am dispassionately serving the ends of objective scholarship, and even so I may offend someone in the audience, and for that I apologize. And yet the chances are that I won't offend very many, because throughout the English-speaking world there has been not so much a coarsening of conversation as more and more formerly taboo usages are used more and in more contexts, but rather a weakening of the mechanisms of swearing, with the result that once fearsome words are losing their capacity to shock - being as it were 'normalized'. Or, as in the case of the masturbatory wank, they cross an ocean and become a harmless part of computerese. Sometimes one wonders if anything is sacred any more.

\section{Pecking orders}

So much then for California, but we aren't finished with American English just yet, because I would like to put to you the idea of a pecking order, not just in the henhouse, but in the world's languages and in the English language. There are some five thousand distinct languages in the world today, many of which are endangered. Some languages, however, occupy powerful positions, like Arabic, Hindi, Mandarin Chinese, and Spanish; others are more or less in the middle, as with Hungarian, Malay, Swahili, and Swedish; others still are small like Icelandic and Welsh; and many really small tongues in places like South America and Asia are endangered, like the panda and the tiger, and may not make it through the next fifty or fifteen or even five years in some cases. But at the top of the top languages comes English, used by anywhere between five hundred and a billion people around the world.

English, however, isn't just a top language with nothing to worry about, because things aren't as simple as that. I've just written a book called The English Languages, suggesting (on what I think is a pretty sound basis) that English can reasonably be regarded as a family of languages rather than just one straightforward homogen(e)ous way of speaking and writing. There are Englishes and Englishes. The English of Liverpool is not at all the same as the English of London, nor the English of the Caribbean much like the English of India, or the English of northern India much like that of southern India, and here in every case we are talking about very large numbers of people: millions of people who are well aware that there isn't just a pecking order among languages but also a pecking order inside World English. Some Englishes, then, are more equal than others, sociopolitically, maybe some of the time and maybe all of the time, and the most equal is that peculiar variety that politicians and teachers and others argue about, the standard language.

But worse, alas, there are different Standard Englishes, and a pecking order seems to operate here as well, where for some people the $B B C$ or $R P$ version of British English is at the top while for others General American - whatever that may precisely be - is the form that everyone turns to, leaving standard Canadian or Australian or South African or New Zealand or Irish or Scottish to do as best they can. People may not know exactly where prestige forms start and stop, but they do know what is not included, and so for example New York English or Southern States American English or African-American Vernacular English - 'black English' - are not included in the general sense of a standard American, in the same way that in the UK today (although language attitudes have softened greatly since mid-century) certain styles of speech are not highly favoured and these are, by and large, the usage of the general populations of the big industrial cities, many rural usages that used to be considered poor stuff now being irradiated by a certain nostalgia, so that purists see them as somewhat higher than everyday non-standard urban usage.

\section{A viable career option}

For good or for ill, the English language complex is unique. No other language has ever before been put to so many uses so massively by so many people in so many places - on every 
continent (including Antarctica); in every sea (including the safety language of shipping, Seaspeak); in the air (including the safety language of aircraft, Airspeak) and in space (with NASAspeak); in thought (which we don't often think about), in speech (what I'm doing now), in writing (what I'm holding here); in print on paper and on screen; in sound on tape and on film; by radio, television, and telephone; and via electronic networks and multimedia; and as one's mother tongue or other tongue, adequately, haltingly, constantly, intermittently, happily, unhappily, or ambivalently by around a fifth of the human race, with millions more joining the club every year in the world's schools.

Edmund Weiner studies English and records it in one of the greatest dictionary enterprises the world has ever seen, the Oxford English Dictionary. It began about 150 years ago, and now proceeds globally with the help of highly sophisticated electronic equipment. I study English, edit a journal entirely devoted to it, and do this for Cambridge. The study of English is an international industry. Tens of thousands of scholars engage in it throughout the world, teaching a student population of millions and producing innumerable books, periodicals, monographs, dissertations, papers, articles, reports, conference proceedings, class notes, course books, newsletters, and Internet contributions. I help direct the Dictionary Research Centre of the University of Exeter, and it is clear from our experience there with placements for our M.A. students that there is plenty of work in the business of English dictionaries as indeed in the teaching of English worldwide. It is and will be for the foreseeable future a viable career option.

\section{Linguistic good neighbourliness}

Yet, oddly enough, this is not a time when native speakers of English can just sit back and congratulate themselves that everybody else has to learn the language we have been born to. It ain't as simple as that. Recently in the International Herald Tribune (3 Nov 95), which is published by Americans in Paris and calls itself - justifiably - 'the global newspaper', Mikie Kiyoi, a Japanese woman, published an article with the title 'Dear English Speakers, Please Drop the Dialects'. In it she says:

It is incontestable that English is the world's most accepted working language. Several centuries of Anglo-American economic and cultural predominance have contributed considerably to the language's status today... I work in an international organization where English is a main working language. Native English speakers have a double advantage at such organizations: Even though they are required to speak a language other than English, that other language is frequently French. And compared with the remoteness of English from my native language - Japanese the difference between English and French is negligible. I have to live with this unfortunate fate: My native tongue is remote from European languages.

Yet I believe I have the right to request that my Anglo-American friends who are involved in international activities not abuse their privilege, even though they do not do so intentionally. First of all, I would like them to know that the English they speak at home is not always an internationally acceptable English... I sincerely believe there exists a cosmopolitan English - a lingua franca, written or spoken - that is clearly different from what native English speakers use unconsciously in their daily life.... We non-natives are desperately learning English; each word pronounced by us represents our blood, sweat and tears. Our English proficiency is tangible evidence of our achievement of will, not an accident of birth. Dear Anglo-Americans, please show us you are also taking pains to make yourselves understood in an international setting.

Such non-native points of view are on the increase, and as the reasonableness of their case becomes apparent further efforts are likely to be made to regularize whatever we mean by International or World Standard English. The assumption of the internationalizers is that everybody - native and non-native alike - should speak distinctly and at an optimal speed, taking turns and not crudely interrupting, and seeking to be aware of different cultural conventions in the world's Englishes. A kind of linguistic good neighbourliness. And native speakers in particular will take care about using slang, jargon, idioms, jokes, and allusions that foreign users may not know, so that they find themselves at a double disadvantage.

All of which is fine, but I am happy to note something new in the commentaries on English as a world language in the last few years. Various observers have been noting that one dominant world language may not in fact mean the end of linguistic diversity. English-speaking people are famous for being monoglots, noting with 


\section{Sound familiar?}

There may be an element of current global social comment in the following excerpt from the Introduction to the linguist Marc Okrand's 'The Klingon Dictionary: The Official Guide to Klingon Words and Phrases', Pocket Books (Simon \& Shuster, New York, 1985).

Although Klingons are proud of their language and frequently engage in long discussions about its expressiveness and beauty, they have found it impractical for communication outside the Klingon Empire. For intra- and intergalactic communication, the Klingon government, along with most other governments, has accepted English as the lingua franca. In general, only those Klingons of the upper classes (which include higher-level governmental and military officials) learn English. As a result, English has taken on two additional functions in Klingon society. First, it is used as a symbol of rank or status. Those Klingons who know English will use it among themselves to show off their erudition and make their place in society known to all who happen to be listening Second, English is used when it is thought best to keep servants, soldiers, or even the general populace uninformed. Thus, on a Klingon vessel, the commanding officer will often speak Klingon when giving orders to his crew, but choose English when having discussions with his officers. On the other hand, a Klingon officer may use Klingon in the presence of non-Klingons to prevent them from knowing what is going on. This use of Klingon seems to be quite effective.

relief that other people will have to learn their language. Soon the majority of speakers - and I mean competent speakers - of English in the world will be non-natives: maybe by 2130 a billion of them to half a billion of us. That is, they will be at least bilingual in one other language and English. This will place all the unilingual Anglophones at a communicative and cultural disadvantage, and will mean that the world view of language use will be predominantly multilingual. It also however appears to mean that English will massively mix with other languages to form a range of Anglo-hybrids such as Spanglish, as when someone says 'Sometimes I start a sentence in English y termino en español' ('... and end in Spanish'), a condition already widespread in the United States.

English has in fact always mixed freely with other languages, and the future appears likely to be a continuation of this. Indeed, even interstellar tongues get in on the act. An academic linguist in California, Marc Okrand, was asked a few years ago to provide some Klingon words for an episode of Star Trek. He duly did, creating a language appropriate to these gruff, snarling warrior aliens (see panel). Out of that invitation Okrand has since spun a series of books that started with The Klingon Dictionary of 1985. There are now, mirabile dictu, even university courses in Klingon, which has become a popular new American language. So, let me leave you now with the handy phrase $J o l ~ Y l c h u$ - which is the rough Klingon equivalent of 'Beam me up, Scotty'. This, along with 'to boldly go' and 'It's life, Jim, but not as we know it', has become part of English as we all now know it.

EU 